13 Kuss, F.R. and Morgan, J.M. (1980) /. Soil Water Conserv. 35, 87-89

14 Liddle, M.J. and Greig-Smith, P.J. (1975)

l. Appl. Ecol. 12, 909-930

15 Warwick, S.I. and Briggs, D. (1978) New Phytol. 81, 711-723

16 Warwick, S.I. and Briggs, D. (1978) New

Phytol. 81, 725-737

17 Stillingfleet, B. (1759) Observations on

Grasses in Miscellaneous Tracts Relating to

Natural History. Husbandry and Physick,

London

18 Tuxen, R. (1950) Mitteilungen der

Floristisch-soziologischen

Arbeitsgemeinschaft (Vol. 2), Glenewinkel

19 Burden, R.F. and Randerson, P.F. (1972)

J. Appl. Ecol. 9, 439-457

20 Godfrey, P.J. (1975) The Ecological Effects of Off-road Vehicles in Cape Cod National

Seashore, Massachusetts (Phase II).

National Park Service Co-operative

Research Unit, Report No. 18, University of

Massachusetts

21 Liddle, M.J. and Kay, A.M. (1987) Biol.

Conserv. 42, $1-18$

22 Kay, A.M. and Liddle, M.J. (1989) Environ

Manage. 13, 509-520

23 Grabherr, G. (1985) in The Ecological

Impacts of Outdoor Recreation on Mountain

Areas in Europe and North America
(Bayfield, N.G. and Barrow, G.C., eds), pp. 74-91, Recreation Ecology Research Group. Ashford, Kent

24 Jim, C.Y. (1987) Environ. Conserv. 14 $117-127$

25 Hall, C.N. and Kuss, F.R. (1989) Biol. Conserv. 48, 211-227

26 Pryor, P.J. (1985) In The Ecological

Impacts of Outdoor Recreation on Mountain Areas in Europe and North America

(Bayfield, N.G. and Barrow, G.C., eds). pp

53-62, Recreation Ecology Research Group Ashford, Kent

27 Warwick, S.I. and Briggs, D. (1979) New Phytol. 83, 509-536

28 Pradhan, P. and Trepathi, R.S. (1983)

Oecol. Plant. 4, 345-353

29 Shields, L.M. and Dean, H.C. (1949) Am.) Bot. 36, 408-416

30 Bayfield, N.G. (1979) Biol. Conserv. 15 165-179

31 Holms, D.O. and Dobson, H.E.M. (1976) Ecological Carrying Capacity Research Yosemite National Park: Part I, The Effects of Human Trampling and Urine on

Subalpine Vegetation, and Survey of Past and Present Back-country Use, California University, Berkeley

32 Liddle, M.J. (1984) in The Ecological Basis of Interactions Between Organisms
(AES Monograph //84) (Liddle, M.). and Tothill, T.C. eds), pp. 113-128

Australian Environmental Studies, Griffith University, Brisbane

33 Watson, A. (1985) Biol. Conserv. 33

369-381

34 Yalden, P.E. and Yalden, D.W. (1988) Biol. Conserv. 44, 213-227

35 Bayfield, N.G. (1973)). Appl. Ecol. 10 635-644

36 Bayfield, N.G. and Lloyd, R.f. 11971$)$ in Pennine Way Survey (Bayfield, N.G. and Brotheton, I., eds), pp. 34-57, Countryside

Commission, Cheltenham

37 Lance, A.N., Baugh, I.D. and Love, J.A

(1989) Biol. Conserv. 49, 201-214

38 Mortensen, C.O. (1989) J. Soil Water

Conserv. 4, 156-159

39 Liddle, M.J. (1975) Biol. Conserv. 8

25 l-255

40 Bell, K.L. and Bliss, L.C. 19731 Biol.

Conserv. 5, 25-32

41 Kellomaki, S. (1973) Silva Fenn. 7 ,

96-113

42 Raunkier, C. (1934) The Life Forms of

Plants and Statistical Plant Geography,

Oxford University Press

43 Shimwell, D.W. (197) ) Description and

Classification of Vegetation. Sidgwick $\varepsilon$

lackson
The spread of African honey bees in South and Central America is one of the most remarkable and certainly among the most highly publicized instances of biological invasion. Their aggressive nest defense has led to numerous stinging incidents and even deaths; agaressiveness, coupled with a tendency to abandon the nest when disturbed, has also caused serious disruption of beekeeping and pollination industries in regions that they have invaded'. The rapid spread of African bees in the Americas and their recent arrival in the United States have sparked interest in development of genetic tools for identification of honeybee populations. This in turn has renewed interest in honeybee biogeography.

The western honey bee, Apis mellifera, is native to Europe, Africa and the Middle East. It encounters a wide range of climates and habitats, which are reflected in numerous geographic races or subspecies. Early studies of honeybee biogeography focused on morphological differentiation of these subspecies; morphological measure-

Deborah Smith is at the Museum of Zoology, Insect Division, and Laboratory for Molecular Systematics, University of Michigan, Ann Arbor, MI 48109, USA.

\title{
African Bees in the Americas: Insights from Biogeography and Genetics
}

\author{
Deborah Roan Smith
}

ments are still the most widely used method for distinguishing African and European honey bees in the Americas ${ }^{2}$. Ruttner ${ }^{3}$ has reviewed and summarized the largc body of literature on honeybee biogeography and morphometrics. recognizing 24 subspecies. Principal component analysis of morphological characters indicated three groups of Apis mellifera subspecies: a sub-Saharan or tropical African group; a north African and western Mediterranean group; and a Middle Eastern and southeast European group $^{3.4}$

Ruttner $^{4}$ proposed that these three groups reflect Apis mellifera's colonization of Europe and Africa from a hypothesized origin in northeast Africa or the Middle East, one lineage would have spread around the eastern end of the Mediterranean basin, a second lineage around the southern and western
Mediterranean, and a third into subSaharan Africa. Subsequently, each of these populations was further subdivided into the subspecies recognized today, presumably by differentiation in isolation. For example, during the Pleistocene glaciations, European honeybee populations would have been isolated in refugia in warmer Mediterranean peninsulas; African populations may have been isolated by alternate expansion and contraction of forest and savannah.

Additional information for study of honeybee biogeography came with the widespread application of protein electrophoresis to population biology. Though early studies of honeybee isozymes indicated very low levels of polymorphism, subsequent investigation has uncovered eight polymorphic loci ${ }^{5,6}$ Some polymorphisms are rare alleles which occur sporadically in 
Table I. Allele frequencies for cytoplasmic malate dehydrogenase $(M d h I)$ and hexokinase $(H k)$, for the honeybee subspecies discussed in the text

\begin{tabular}{|c|c|c|c|c|c|c|c|c|c|}
\hline Subspecies & Locality & $\begin{array}{l}\text { No. of } \\
\text { hives }\end{array}$ & $\begin{array}{l}\text { No. of } \\
\text { bees }\end{array}$ & \multicolumn{5}{|c|}{ Allele frequencies } & Refs \\
\hline & & & & \multicolumn{5}{|c|}{ Mdh1 alleles } & \\
\hline & & & & $S(65)$ & $M(80)$ & $(87)$ & $F(100)$ & VF (137) & \\
\hline mellifera & Norway & 6 & 405 & 0.04 & 0.85 & 0 & 0.11 & 0 & 31 \\
\hline scutellata & S. Africa & 10 & 460 & 0 & 0 & 0 & 1.00 & 0 & 9 \\
\hline scutellata & S. Africa & 15 & 278 & $<0.01$ & $<0.01$ & 0 & 0.99 & 0 & 16 \\
\hline ligustica & N. Italy & - & 220 & 0.75 & 0.02 & 0 & 0.23 & 0 & 32 \\
\hline \multirow[t]{3}{*}{ ligustica } & N. Italy & 5 & 313 & 0.64 & 0 & 0.07 & 0.29 & 0 & 33 \\
\hline & & \multicolumn{8}{|c|}{ HK alloles } \\
\hline & & & & \multicolumn{2}{|r|}{$\mathrm{S}(87)$} & \multicolumn{2}{|r|}{$F(100)$} & & \\
\hline mellifera & Norway & 6 & 180 & \multicolumn{2}{|r|}{0} & \multicolumn{2}{|r|}{$1.00^{\mathrm{a}}$} & & 31 \\
\hline scutellata & S. Africa & 15 & 263 & \multicolumn{2}{|r|}{0.71} & \multicolumn{2}{|r|}{0.29} & & 16 \\
\hline ligustica & N. Italy & 5 & 120 & \multicolumn{2}{|r|}{0} & \multicolumn{2}{|r|}{$1.00^{\mathrm{a}}$} & & 33 \\
\hline ligustica & N. Italy & 15 & 90 & \multicolumn{2}{|r|}{0} & \multicolumn{2}{|r|}{1.00} & & 7 \\
\hline carnica & Germany & 12 & 96 & \multicolumn{2}{|r|}{0} & \multicolumn{2}{|r|}{1.00} & & 7 \\
\hline
\end{tabular}

In these studies hexokinase was found to be monomorphic, and it is assumed that the Hk allele present is the common European 'fast' or ' 100 ' form; however, these authors did not have samples of the slow allele available for comparison.

several populations. Others show allele frequency differences between subspecies: cytoplasmic malate dehydrogenase (MdhI) and hexokinase $(H k)$ allele frequencies differ between European subspecies and African A. m. scutellata (Table 1), and have been used in the study of African bees in the Americas $^{7-11}$.

The first published study of honeybee mitochondrial DNA (mtDNA) suggested that there might be little variation among subspecies ${ }^{12}$. Subsequent work on samples drawn from a greater part of Apis mellifera's natural range (Fig. 1 b) revealed substantial variation in length and restriction endonuclease cleavage sites $^{13-16}$.

The mtDNA data, like the morphometric data, indicate three lineages within Apis mellifera: a western European, an eastern Mediterranean, and an African group (Table 2). The groupings indicated by the two data sets are generally similar; where they differ is in the placement of north African populations. Morphometric data would place Egyptian A. $m$. lamarckii with the tropical African bees, and unite A.m. mellifera, intermissa, iberica and the remaining north African bees in a west Mediterranean group (Fig. la). According to the evidence from mtDNA (Fig. Ib), A. m. lamarckii is similar to the bees of south and eastern Europe, while the other north African subspecies are joined with bees of sub-Saharan Africa in a single African lineage. Apis $m$. mellifera and some iberica make up the western European group. Western European and African bees apparently come into (secondary?) contact and hybridize in Spain, where both western European and African mtDNAs occur in $A . m$. iberica (D.R. Smith et al. unpublished): west European melliferalike mtDNA predominates in the north, while African intermissa-like mtDNA predominates in the south.

There is much less differentiation of mtDNAs among subspecies within each lineage (Table 2). Although further study is needed to clarify this, some subspecies (e.g. A. m. carnica and ligustical may differ only in the frequency of mitochondrial types present in both subspecies. Surveys of mtDNA from Spanish and South African honey bees indicate that the four-base restriction enzyme Hinfl distinguishes 'African' A. $m$. iberica (with intermissa-like mtDNA) from South African A. m. scutellata (D.R. Smith et al. unpublished).

\section{Honey bees in the New World}

The history of honey bees in the New World (summarized by Sheppard ${ }^{17}$ ) to some extent reflects colonization of the New World by European people. In the 1500s, Spanish colonists brought their local honey bees, $A$. $m$. iberica, to the Americas. In the 1600s and 1700s, colonists from England and northwestern Europe imported $A . m$. mellifera. In the mid-1800s additional races were imported, and three of these - A. m. carnica from southeastern Europe, A. m. caucasica from the Caucasus, and $A . m$. ligustica from Italy - were favored by beekeepers; by the turn of the century they had virtually replaced other subspecies in domesticated North American populations, though in parts of South America, descendants of $A . m$. mellifera are common in apiary populations ${ }^{8}$. Further importation of honey bees to the United States was prohibited by the Honeybee Act of 1922. While European honey bees escaped from cultivation and established thriving feral populations in temperate North America, they did not fare as well in tropical South and Central America, and were unable to establish large feral populations there ${ }^{18}$.

In 1956, geneticist and beebiologist Warwick Kerr imported 47 queens of South African and Tanzanian A. m. scutellata to Brazil, with the goal of creating a hybrid strain of bee better suited to neotropical conditions ${ }^{19}$. Within a few years, a feral population of bees with behavioral and morphological traits like those of the imported African bees became established there. A widely accepted account ${ }^{19}$ of the origin of this population is that an accident allowed 26 colonies to escape from culture and establish a feral population. (Unfortunately, this account leaves many questions unresolved. Was there a single introduction of 47 queens, or were multiple introductions made by other bee-breeders? Did the sample of African bees introduced represent a single population or multiple genetically distinct populations? And to what extent was the early spread of African bees in South America human-assisted? ।

In the 34 years since the introduction of these bees to Brazil, they have spread over most of South and Central America ${ }^{20}$, and come into contact with large domesticated populations of European honey 
(a)

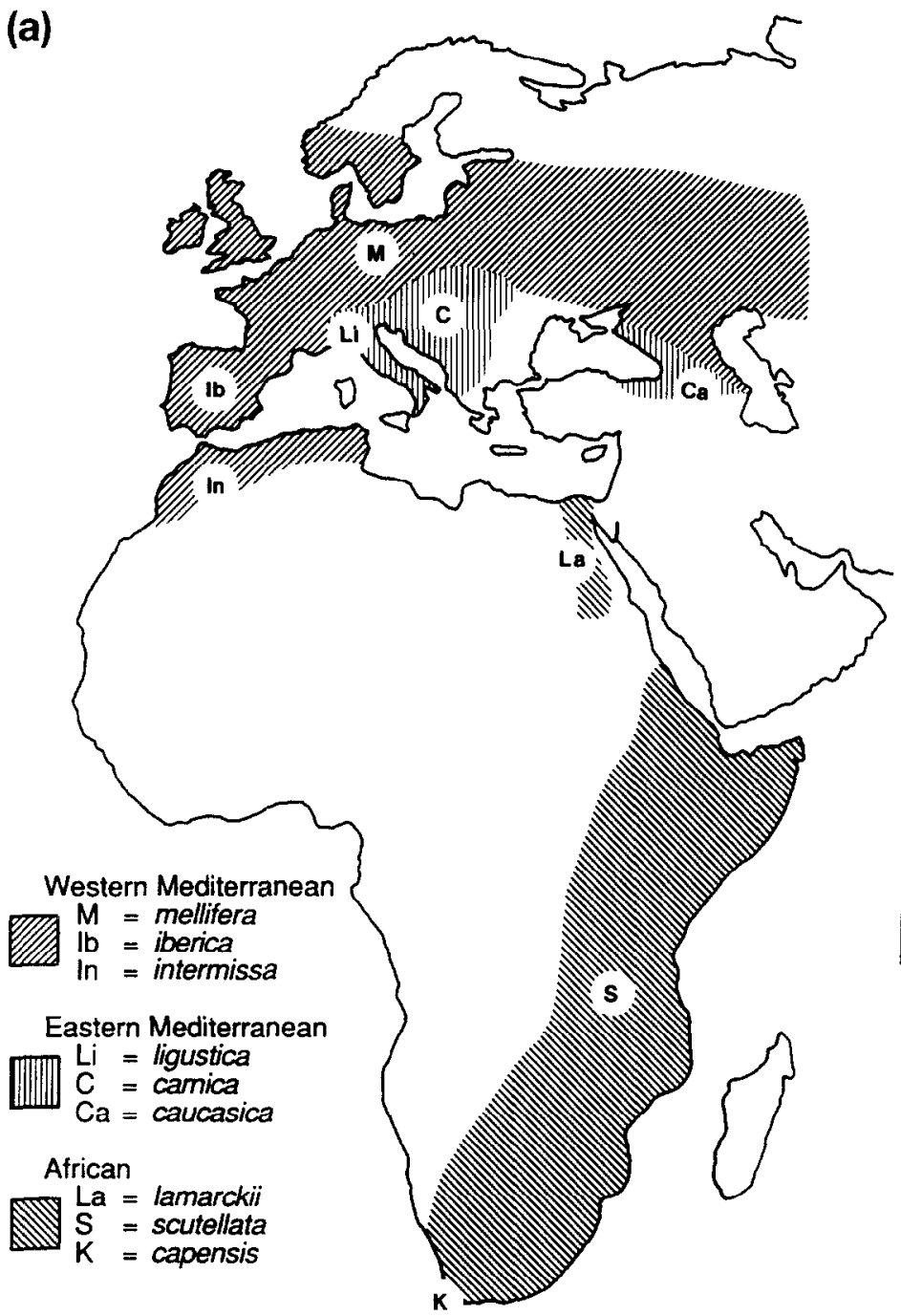

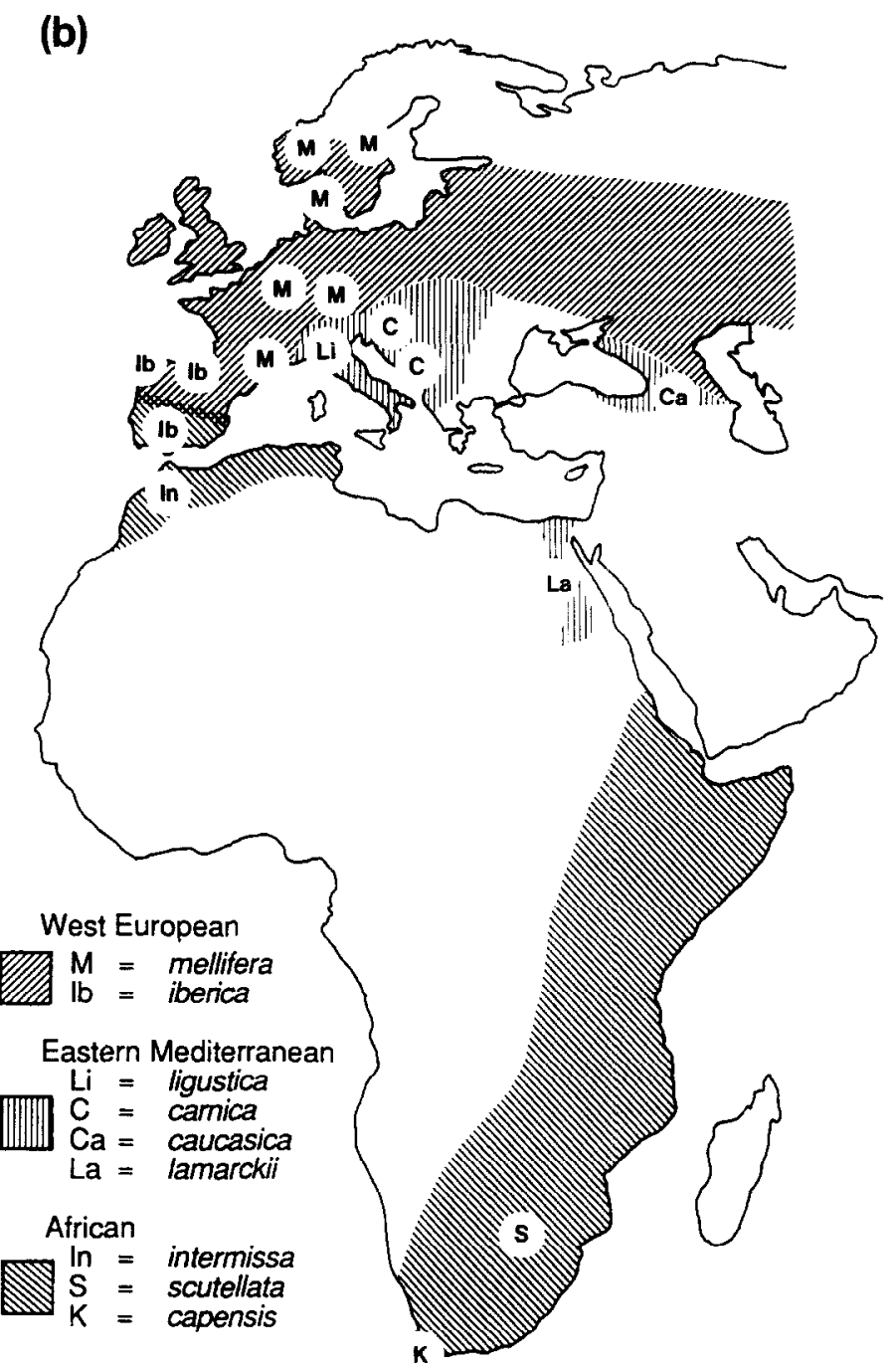

Fig. I. lal Morphometric studies of honeybee subspecies indicate three major lineages within Apis mellifera, as shown here for the subspecies discussed in the text ${ }^{3.4}$. (bI Mitochondrial DNA data also indicate three lineages within Apis mellifera, shown here for the subspecies discussed in the text (Refs $13-16$ and D.R. Smith et al. unpublishedI. Letters indicate approximate collection sites for each subspecies studied.

bees. Nonetheless, they have retained African behavioral' ${ }^{21}$, morphological ${ }^{2,22}$ and allozyme ${ }^{9.11}$ characteristics, despite the obvious potential for interbreeding with European bees and introgression of European characters.

Study of the population biology of neotropical African and Africanized bees (Box 1 ) in the Americas has suffered from two problems. First, a great deal of effort has been devoted solely to identification, that is, classification of bees as either African/Africanized or European. This is useful and necessary for practical management purposes but obscures the fact that these are interbreeding populations. Second, many studies of African bees in the New World have focused on apiary populations, ignoring feral African populations. This makes it difficult to determine if the feral and domestic African bees actually constitute a single population or partially isolated populations. The studies reviewed here document the genetic composition of these populations, and provide evidence about the pattern of gene flow among them.

Paternal gene flow from the feral neotropical African population to the managed European population is well known. Young apiary queens mate with neotropical African

drones and produce hybrid offspring. This interbreeding between European and neotropical African bees leads to rapid 'Africanization' of European apiaries: worker bees in these hives show morphological and behavioral characteristics typical of the African population. African maternal lineages can also enter
Table 2. Mitochondrial sequence divergence within and among honeybee lineages ${ }^{a}$

\begin{tabular}{ll}
\hline Lineages & Percentage sequence divergence ( \pm sD) \\
\hline Within lineages & \\
East Mediterranean (carnica and ligustica) & $0.3 \%( \pm 0.3)$ to $0.9 \%( \pm 0.5)$ \\
West European (mellifera and iberica) & $0.3 \%( \pm 0.3)$ to $1.0 \%( \pm 0.6)$ \\
African (scutellata, capensis and intermissa) & $0.3 \%( \pm 0.3)$ to $1.3 \%( \pm 0.7)$ \\
& \\
Among lineages & \\
East Mediterranean/West European & $2.3 \%( \pm 0.9)$ to $3.7 \%( \pm 1.2)$ \\
East Mediterranean/African & $2.0 \%( \pm 0.8)$ to $3.7 \%( \pm 1.2)$ \\
West European/African & $2.0 \%( \pm 0.8)$ to $3.4 \%( \pm 1.2)$ \\
\hline
\end{tabular}

aThe percentage sequence divergence (see Ref. 34) between honeybee mitochondria genomes (i.e. the percentage of base pairs that have undergone mutation since two lineages diverged) was estimated from restriction enzyme cleavage site maps for each subspecies. Data from Refs 13-16 and D.R. Smith et al. unpublished. 


\section{Box 1. Terminolog tor bee populations}

To avoid confusion, the term European beos is used here to refer to feral or domestic populations descended from one or more European subspecies, primarily $A . m$. mellifera, ligustica, carnica and caucasica. The term nostrealed Ahican bees refers to feral populations descended entirely or in part from the African subspecies A $m$. scutellata. The term Arricantzed bees is used only for European aplary populations that have hybridized with neotropical African bees.

apiary populations: swarms headed by African queens are sometimes able to take over weak European colonies $^{18}$. More commonly, beekeepers add to their stock by capturing wild swarms, which in many areas are likely to be neotropical African bees.

The extent of gene flow from the European population to the feral neotropical African population, and its source, whether from males or from females, is more controversial Colonies of African and Africanized bees produce more drones ${ }^{23}$ and more swarms than typical European bees $^{24,25}$. Thus, in Africanized apiaries the hybrid offspring of European mothers and Africanized or neotropical African fathers produce large numbers of swarms, many of which escape from cultivation. The fate of these swarms is a crucial element in determining the pattern of gene flow from European to neotropical African populations. Because insect mtDNA is maternally inherited it can be used to trace the movements of swarms. If Africanized swarms successfully join the feral neotropical African population, then a substantial fraction of mitochondrial genomes in that population should be European, since swarms dispersing from Africanized apiaries carry the European mtDNA of their maternal ancestors. If Africanized swarms do not make substantial contributions to the neotropical African population, there should be very little European mtDNA in the feral African population.

\section{Evidence from $m t D N A$}

The mtDNA of neotropical African bees $^{16,26}$ was surveyed with a set of restriction enzymes that distinguish African $A$. $m$. scutellata from European $A . m$. mellifera, carnica, ligustica and caucasica. Fifty-four of 55 feral Mexican swarms and 21 of 22 samples of Venezuelan and Brazilian neotropical African or
Africanized colonies had African mtDNA; only two hives had European mtDNA.

It is also important to distinguish the mtDNA of South African A. $m$. scutellata from that of any relictual populations of Spanish or Portuguese A. m. iberica, some of which have mtDNA belonging to the African group of mtDNAs. Hinfl digests of the same set of neotropical African mtDNAs (D.R. Smith, unpublished) showed that the neotropical Africans resembled $A . m$. scutellata, not iberica. (This does not mean that populations descended from $A$. $m$. iberica do not exist; they may yet be detected in areas of northern Mexico and the southwestern United States where the climate is more similar to that of southern Spain.)

Thus, the neotropical African population consists largely of the matrilineal descendants of $A . m$. scutellata, and is expanding primarily by dispersal of swarms. Although Africanized apiaries are known to produce large numbers of swarms carrying European mtDNAs, these do not appear to make a substantial contribution to the feral African population. We do not know why. It may be, for example, that there is active selection against European and European-African hybrids in the tropical environment; or the number of Africanized swarms may be small relative to the number of swarms produced by the large neotropical African population, so that the European mitochondrial genomes are swamped by more numerous African oncs ${ }^{27}$. (However, the latter explanation begs the question of how the large, feral population with African mtDNA became established.)

\section{Evidence from the nuclear genome}

The evidence of mtDNA addresses only half of the problem. Have neotropical African bees bred extensively with European drones? At this point the answer seems to be no, although more research is needed. Evidence comes from morphometrics, allozymes, and most recently, nuclear restriction fragment length polymorphisms.

Boreham and Roubik ${ }^{22}$ monitored swarms of neotropical African bees in Panama over a 48-month period beginning in 1982, when the first
African swarms were detected in the Panama Canal area. Their morphometric measurements showed that the feral African population was 'strongly Africanized' (i.e. smaller) throughout the study, but the bees collected in later months (19841985I were significantly smaller than the bees collected in 1982. Assuming that lother conditions being equal) larger bees have a higher proportion of European ancestry than smaller bees, it appears that when African bees enter a new region and are numerically inferior, mating occurs between European drones and African queens. Later, as the feral African population increases, introgression from the European population is less apparent.

On the other hand, a morphological study of feral neotropical African bees in Venezuela ${ }^{28}$ showed that they were larger, and morphologically distinguishable from South African A. m. scutellata, implying gene flow from European apiary populations. However, this study is difficult to interpret for two reasons: (1) it is not clear whether the feral population studied included swarms newly escaped from apiary populations $\left(F_{1}\right.$ crosses between European and feral Africans); and (2) no data are presented comparing the feral neotropical African population to European bees, though the authors state that 18 of the 24 morphological measurements made were more similar to African than to European bees.

Recent studies using allozyme frequencies to assess the genetic composition of neotropical African and Africanized population $5^{7,8.10}$ indicate a high frequency of alleles typical of A. m. scutellata (Mdh/100 and $H k^{87}$ : Table 11 , and a low, though variable, frequency of alleles typical of European subspecies. Lobo et al. ${ }^{\triangleright}$ estimated the genetic contribution of $A . m$. scutellata, mellifera and ligustica to feral honeybee populations in Brazil and Uruguay by comparing $M d h /$ allele frequencies in these populations with those found in Old World populations of each subspecies. They estimated that the genetic contribution of $A . m$. scutellata was in excess of $70 \%$ in each population sampled, while the contribution of $A . m$. ligustica was less than $4 \%$. The contribution of $A$ $m$. mellifera ranged from $13 \%$ in 
northeastern Brazil to $26 \%$ in southwestern Brazil and Uruguay. Del Lama et $a l^{7}$ found that the frequency of the $H k^{87}$ allele in Brazilian populations ranged from 0.44 to 0.65 , being lowest in southwestern Brazil.

Spivak et al..$^{10}$ investigated both $M d h I$ and $H k$ allele frequencies in Costa Rican honey bees from 1984 until 1988, when African bees began to enter the area, and compared them with European populations from Costa Rica and the United States. They found the frequency of the $M d h l^{100}$ and $H k^{87}$ alleles to be high (0.82 and 0.40 , respectively) in strongly Africanized hives, lower in the intermediate hives $(0.50$ and $0.3 \mathrm{~b}$ and lowest in European hives 0.35 and 0.15 in Costa Rican hives, 0.37 and 0.0 in North American hives).

Recently, nuclear restriction fragment length polymorphisms (RFLPs) have been found that are unique to certain European subspecies ${ }^{29,30}$. Three single-locus markers are present in high frequency $(70-75 \%)$ in European $A . m$. ligustica and carnica and absent in South African $A$. $m$. scutellata. The frequency of these markers in samples from wild-caught swarms of neotropical African bees and in colonies established from wild-caught swarms ranged from 8 to $18 \%$ in samples from southern Mexico collected in 1988, when the African population had recently arrived. The markers were present in low frequency in Costa Rican neotropical African samples and in Venezuelan samples from colonies established from wild-caught swarms, and absent in Venezuelan swarms newly captured in 1988. These data again indicate that there is gene flow from European populations to the neotropical African population, but at least in tropical populations the amount is relatively small.

\section{Conclusion}

The broad outlines of the story are now apparent. The evidence from mtDNA shows that relatively few queens with European mtDNA have contributed to the feral neotropical African population, which has expanded and colonized new territory by female dispersal (swarming). Nuclear markers (allozymes and RFLPs) show that neo- tropical African populations have African markers in high frequency and European markers in low frequency, indicating that there is gene flow from the European to the neotropical African population (presumably via males), but that the nuclear genomes of neotropical African bees maintain a large African component. The amount of introgression from European honey bees undoubtedly varies from region to region, depending on such factors as size of commercial apiaries in the area, their management, the particular subspecies represented in the European population, and climatic factors.

Given the outlines of the story, further research is needed. The first requirement is careful sampling of both feral and domesticated populations in a region before, during and after the arrival of African bees, followed by analysis of nuclear and mitochondrial characters. This will permit the documentation of the pattern and time course of gene flow among populations land will require the application of more sophisticated statistical analysis than has been necessary so far)

A second requirement is a study of competitive interactions between European and African bees in tropical and temperate environments. African bees have been successful colonists in neotropical habitats lacking large feral honeybee populations. In North America, however, 'neotropical' African bees will encounter large feral populations of temperate-adapted European bees. The potential exists either for extensive gene flow between feral European and feral African populations, or for competitive exclusion of African bees by resident feral European populations. A study of the apparently stable boundary between European and African bees in Spain may provide clues to the nature of gene flow between these two populations over an area of ecological transition, and insight into the eventual outcome of competition between European and African honey bees in North America.

\section{References}

1 Taylor, O.R. (1988) in Africanized Honey Bees and Bee Mites (Needham, G.R., Page, R.E., Jr, Delfinado-Baker, M. and Bowman,
C.E., eds), pp. 29-4l, Ellis Horwood 2 Daly, H.V. and Balling. S.S. (1978) I. Kans. Entomol. Soc. 51, 857-869

3 Ruttner, F. (1988) Biogeography and Taxonomy of Honey Bees, Springer-Verlag 4 Ruttner, F., Tassencourt, L. and Louveaux J. (1978) Apidologie 9, 363-381

5 Sylvester, H.A. (1986) in Bee Genetics and Breeding (Rinderer, T.E., ed.), pp. 177-203 Academic Press

6 Sheppard, W.S. and Huettel, M.D. (1988) in Africanized Honey Bees and Bee Mites (Needham, G.R., Page, R.E., Ir, DelfinadoBaker, M. and Bowman, C.E., eds), pp 281-286, Ellis Horwood

7 Del Lama, M.A., Figueiredo, R.A., Soares, A.E.E. and Del Lama, S.N. (1988) Rev. Brazil Genet. 11, 287-297

8 Lobo, J.A., Del Lama, M.A. and Mestriner M.A. (1989) Evolution 43, 794-802

9 Nunamaker, R.A. and Wilson, W.T. (198I)

I. Kans. Entomol. Soc. 54, 704-710

10 Spivak, M., Ranker, T., Taylor, O.R.

Taylor, W. and Davis, L. (1988) in Africanized Honey Bees and Bee Mites (Needham, G.R Page, R.E., Jr, Delfinado-Baker, $M$ and Bowman, C.E., eds), pp. 313-324, Ellis Horwood

11 Sylvester, H.A. (1982)/. Apic. Res. 21, 93-97

12 Moritz, R.F.A., Hawkins, C.F., Crozier, R.H and MacKinley, A.G. $(1986)$ Experientia 42 , 322-325

13 Smith, D.R. (1988) in Africanized Honey Bees and Bee Mites (Needham, G.R., Page, R.E., Ir, Delfinado-Baker, M. and Bowman, C.E., eds), pp. 303-312, Ellis Horwood 14 Smith, D.R. and Brown, W.M. (1988) Experientia 44, 257-260

15 Smith, D.R. and Brown, W.M. (1990) Ann. Entomol. Soc. Am. 83, 81-88

16 Smith, D.R., Taylor, O.R. and Brown, W.M. ( I 989) Nature 339, 213-215

17 Sheppard, W.S. (1989) Am. Bee I. 129 617-619 and 664-666

18 Michener, C.D. (1975) Annu. Rev. Entomol. 20, 399-416

19 Kerr, W.E. (1967) S. Afr. Bee I. 39, 3-5 20 Taylor, O.R. (1985) Bull. Entomol. Soc. Am. 31, 14-24

21 Collins, A.M., Rinderer, T.E., Harbo, J.R. and Bolten, A.B. $(1982)$ Science $218,72-74$ 22 Boreham, M.M. and Roubik, D.W. (1987) Bull. Entomol. Soc. Am. 33, 34-39

23 Rinderer, T.E., Hellmich, R.L., II, Danka, R.G. and Collins, A.M. (1985) Science 228, 1119-1121

24 Otis, G.W. (1982) in Social Insects in the Tropics (Jaisson, P., ed.), pp. 209-219, Université Paris-Nord

25 Winston, M.L. (1979) Behav. Ecol Sociobiol. 4, 279-292

26 Hall, H.G. and Muralidharan, K. (1989) Nature $339,211-213$

27 Page, R.E., Ir (1989) Nature 339, 181-182 28 Buco, S.M. et al. (1987) Apidologie 18 217-222

29 Hall, H.G. (1986) Proc. Natl Acad. Sci. USA $83,4874-4877$

30 Hall, H.G. (1990) Genetics 125,611-621

31 Sheppard, W.S. and Berlocher, S. (1984) I. Apic. Res. 23, 64-69

32 Badino, G., Celebrano, G., Manino, A. and Longo, S. (1985) Experientia 41, 752-754

33 Sheppard, W.S. and Berlocher, S. (1985)

J. Hered. $76,45-48$

34 Nei. M. and Tajima, F. (1983) Genetics $105,207-217$ 